\title{
Human Fat Cell Lipolysis Is Primarily Regulated by Inhibitory Modulators Acting through Distinct Mechanisms
}

\author{
H. Kather, W. Bieger, G. Michel, K. Aktories, and K. H. Jakobs \\ Klinisches Institut für Herzinfarktforschung an der Medizinischen Universitätsklinik, Medizinische Poliklinik der Universität, and \\ Pharmakologisches Institut der Universität Heidelberg, D-6900 Heidelberg, Federal Republic of Germany
}

\begin{abstract}
The effects of adenosine deaminase and of pertussis toxin on hormonal regulation of lipolysis were investigated in isolated human fat cells. Adenosine deaminase $(1.6 \mu \mathrm{g} / \mathrm{ml})$ caused a twoto threefold increase in cyclic AMP, which was associated with an increase in glycerol release averaging $150-200 \%$ above basal levels. Clonidine, $N^{6}$-phenylisopropyladenosine, prostaglandin $\mathbf{E}_{2}$, and insulin caused a dose-dependent inhibition of glycerol release in the presence of adenosine deaminase.

Pretreatment of adipocytes with pertussis toxin $(5 \mu \mathrm{g} / \mathrm{ml})$ for $180 \mathrm{~min}$ resulted in a five- to sevenfold increase in cyclic AMP. Glycerol release was almost maximal and isoproterenol caused either no further increase or only a marginal additional increase of lipolysis after pretreatment with pertussis toxin, whereas cyclic AMP levels were 500 times higher than in controls. The effects of antilipolytic agents known to affect lipolysis by inhibition of adenylate cyclase activity, i.e., clonidine, $\mathbf{N}^{6}$ phenylisopropyladenosine, and prostaglandin $\mathrm{E}_{2}$, were impaired. In contrast, the antilipolytic action of insulin was preserved in adipocytes pretreated with pertussis toxin. As in controls, the peptide hormone had no detectable effect on cyclic AMP after pertussis toxin treatment.

The findings support the view that the antilipolytic effect of insulin does not require adenylate cyclase or phosphodiesterase action. In addition, the results demonstrate that, upon relief of endogenous inhibition, human fat cell lipolysis proceeds at considerable (adenosine deaminase) or almost maximal (pertussis toxin) rates. A certain degree of inhibition, therefore, appears to be necessary for human fat cell lipolysis to be susceptible for hormonal activation.
\end{abstract}

\section{Introduction}

Human adipose tissue responds to a variety of humoral, hormonal, and neural factors (1). Most of these regulatory influences appear to be mediated via activation or inhibition of adenylate cyclase $(1,2)$. In human fat cells, stimulators of cyclic AMP (cAMP) formation include $\beta$-adrenergic agonists and a single peptide hormone, namely parathyroid hormone (2). $\alpha_{2}$ Adrenergic amines, adenosine, and prostaglandins of the $E$ type, are inhibitors of cAMP production (3-7). Insulin also inhibits lipolysis (1). However, the mechanism by which the antilipolytic effect of insulin is mediated is not understood. It is controversial, for instance, whether insulin regulates adenylate cyclase and

Received for publication 11 June 1984 and in revised form 31 May 1985.

J. Clin. Invest.

(c) The American Society for Clinical Investigation, Inc. 0021-9738/85/10/1559/07 \$1.00

Volume 76, October 1985, 1559-1565 whether the modulation of intracellular cAMP concentrations by the hormone plays a primary role (1).

In addition to the uncertainties regarding the mechanism(s) of action of some hormonal regulators, such as insulin, it has been frequently difficult to relate the effects of hormones in vitro to systemic metabolism in vivo. It is still not clear which hormones are responsible for lipid mobilization during fasting. Lipolysis could be elevated by the drop in plasma insulin that occurs during fasting or by an increased release of lipolytic hormones such as epinephrine (1), two mechanisms of regulation that are fundamentally different. If a drop in insulin, i.e., relief of inhibition, were responsible for increased rates of lipolysis during starvation, this would imply that unrestrained basal lipolysis proceeds at considerable if not maximal rates. By contrast, basal lipolysis could be low or even negligible if starvation-induced activation of lipolysis were brought about by lipolytic hormones.

In vitro basal rates of lipolysis are usually low and substantial rates of lipid mobilization are observed only in the presence of lipolytic hormones, suggesting that lipolysis might, in fact, be primarily regulated by activation. However, fat cells spontaneously produce and release inhibitory compounds such as adenosine and prostaglandins $(2-5,8)$. In order to discern whether basal lipolysis proceeds at maximal or near-maximal rates, it is necessary to eliminate the influence of inhibitory compounds produced during incubation in vitro. Adenosine can be easily removed by enzymic degradation using adenosine deaminase.

Recently, a toxin has been identified and characterized from supernatants of cultures of Bordetella pertussis that elicits a variety of biological responses including induction of lymphocytosis, sensitization of animals to the lethal effects of histamine, stimulation of insulin secretion, and lipid mobilization (9). Pretreatment of rats or hamsters with pertussis toxin impairs or abolishes the in vitro effects on fat cell lipolysis of various antilipolytic agents, including $\alpha$-adrenergic agonists, prostaglandin $E_{2}$, adenosine analogues, and nicotinic acid (10-13). In contrast to the effect of the latter compounds, treatment with pertussis toxin $(10,11)$ preserves the antilipolytic effect of insulin. The toxin offered the opportunity to eliminate not only the effects of adenosine but also of other endogenous inhibitors such as prostaglandins.

By using both adenosine deaminase and the bacterial toxin, we were able to demonstrate that basal human fat cell lipolysis proceeds at considerable rates upon relief of endogenous inhibition, suggesting that lipid mobilization from human fat cells is primarily regulated by inhibition. As in the rat, the antilipolytic action of insulin was preserved after pretreatment of human adipocytes with pertussis toxin, indicating that the mechanisms underlying the antilipolytic effects of insulin are also different from those of other inhibitors such as prostaglandin $E_{2}, N^{6}$ phenylisopropyladenosine, and $\alpha_{2}$-adrenergic amines in human fat cells. 


\section{Methods}

Subjects. Subcutaneous adipose tissue was obtained from 20 obese subjects undergoing elective abdominal surgery. The patients were not selected on the basis of age, sex, or disease. Surgery was performed after an overnight fast. Anesthesia was initiated with a short-acting barbiturate and maintained with oxygen, nitrous oxide, and halothane. Tissue specimens ( $1-10 \mathrm{~g}$ of tissue) were obtained at the start of the operation.

Preparation of fat cells and preincubation. Tissue specimens were cut into small pieces and fat cells were isolated by collagenase digestion according to Rodbell (14) using Krebs-Henseleit bicarbonate buffer, $\mathrm{pH}$ 7.4 , containing $5 \mathrm{mM}$ glucose, $40 \mathrm{~g}$ /liter of human serum albumin, and $0.5 \mathrm{mg} / \mathrm{ml}$ of collagenase (Sigma Chemical Co., St. Louis, MO, type II). After $45 \mathrm{~min}$ of incubation at $37^{\circ} \mathrm{C}$ the fat cells were washed by flotation (three times) and resuspended in the same medium (except that collagenase was omitted) at a concentration of 50,000-200,000 cells $/ \mathrm{ml}$, and preincubated for $180 \mathrm{~min}$ at $37^{\circ} \mathrm{C}$ under an atmosphere of $95 \% \mathrm{O}_{2}$ and $5 \% \mathrm{CO}_{2}$ ( $\left.\mathrm{vol} / \mathrm{vol}\right)$. Where indicated, the medium was fortified with $5 \mu \mathrm{g} /$ $\mathrm{ml}$ of pertussis toxin. Control cells were handled in an identical manner except that no toxin was added. Preincubations were terminated by washing with fresh medium without pertussis toxin. Pertussis toxin was also omitted during subsequent incubations.

Incubations. When glycerol release served as the only end point (see Figs. 2 and 3), cell densities were adjusted to 5,000-20,000 cells/ml and incubations were carried out in stoppered plastic vials in a total volume of $0.05 \mathrm{ml}$ under an atmosphere of $95 \% \mathrm{O}_{2}$ and $5 \% \mathrm{CO}_{2}$ (vol/vol) for a further $180 \mathrm{~min}$. Hormones and adenosine deaminase were added at the start of the final incubations in these latter experiments. Reactions were terminated by heating $\left(95^{\circ} \mathrm{C}, 5 \mathrm{~min}\right)$.

In experiments where cAMP levels and glycerol release were determined concomitantly, higher cell densities (approximately $10^{5}$ cells $/ \mathrm{ml}$ ) and larger assay volumes $(6 \mathrm{ml})$ were used during the final incubations. Preliminary experiments indicated that the onset of the antilipolytic effect of insulin was preceded by a lag of $\sim 10 \mathrm{~min}$. Unless otherwise stated, time-course experiments were, therefore, started 15 min after hormones and adenosine deaminase had been added. At the times indicated, aliquots of 0.5 and $0.05 \mathrm{ml}$ were withdrawn in these latter experiments and assayed for cAMP and glycerol, respectively.

Pertussis toxin. Pertussis toxin was purified to apparent homogeneity according to Cowell et al. (15) from supernatants of Bordetella pertussis suspensions kindly donated by Drs. L. Robbel and F. Backkolb (Behring Werke, Marburg, Federal Republic of Germany). Preliminary experiments indicated that for human adipocytes relatively high concentrations $(1-5 \mu \mathrm{g} / \mathrm{ml})$ of the toxin were needed in order to achieve complete reversal of the antilipolytic effects of prostaglandin $E_{2}$, clonidine, or $\mathrm{N}^{6}$-phenylisopropyladenosine within $180 \mathrm{~min}$ at $37^{\circ} \mathrm{C}$. Therefore, a concentration of $5 \mu \mathrm{g} / \mathrm{ml}$ of pertussis toxin was used throughout in the present studies. As in other cell types or species, pertussis toxin increased basal glycerol release with a lag of 90-120 min under these conditions.

Assays. The glycerol content of the deproteinized media was measured by a bioluminescent method using an automatic luminescence analyzer (Berthold LB 950 T). A manual version of this method has been described in detail elsewhere $(16,17)$. The use of an automatic analyzer required some minor modifications. Briefly, $0.05 \mathrm{ml}$ of the appropriately diluted samples (2-10 times) were added to an equal volume of a medium composed of $28 \mathrm{nmol} /$ liter triethanolamine- $\mathrm{HCl}, 1.1 \mathrm{mmol} /$ liter $\mathrm{KH}_{2} \mathrm{PO}_{4}$, $20 \mathrm{nmol} /$ liter $\mathrm{Na}_{3} \mathrm{AsO}_{4}, 1.1 \mathrm{mmol} /$ liter dithiotreitol, $2.9 \mathrm{mmol} / \mathrm{liter}$ $\mathrm{MgCl}_{2}, 1.54 \mathrm{mmol} /$ liter ATP, $8.0 \mathrm{mmol} /$ liter NAD, $7 \mathrm{U} / \mathrm{ml}$ glycerokinase, $19 \mathrm{U} / \mathrm{ml}$ glyceraldehyde 3-phosphate dehydrogenase, $2.3 \mathrm{U} / \mathrm{ml}$ glycerol 3-phosphate-dehydrogenase, and $33 \mathrm{U} / \mathrm{ml}$ triosephosphate-isomerase. After incubation for $120 \mathrm{~min}$ at $37^{\circ} \mathrm{C}$, the samples were further diluted (six times) and $0.01-\mathrm{ml}$ aliquots of the diluted media were assayed for $\mathrm{NADH}$. The assay cocktail for the luciferase reaction contained $0.5 \mathrm{mmol} /$ liter tetradecanal $1.1 \mu \mathrm{mol} / \mathrm{liter}$ flavin mononucleotide, $15 \mathrm{U} / \mathrm{liter}$ bacterial luciferase, and 8.5 U/liter NAD(P)H:flavin mononucleotide oxidoreductase. The assay cocktail was prepared daily and held at $+2^{\circ} \mathrm{C}$ during measurements. Light production was measured by a microcomputer-controlled automatic luminescence analyzer. The vials containing
$0.01 \mathrm{ml}$ of sample were automatically moved into the measuring position. The reaction was started by automatic injection of the assay cocktail. Measuring time was $15 \mathrm{~s}$. The integral of counts between 10 and $15 \mathrm{~s}$ was taken as a measure of NADH concentration.

cAMP was determined after acetylation using a commercially available radioimmunoassay (NEN Chemicals, Dreieich, Federal Republic of Germany). Fat cell number was determined by counting all cells in appropriately diluted aliquots $(10 \mu \mathrm{l})$ of the cell suspension.

Chemicals. Collagenase (type II) was from Sigma Chemical Co. All other enzymes and coenzymes and $\mathrm{N}^{6}$-phenylisopropyladenosine were from Boehringer Mannheim, Federal Republic of Germany. Ammonium sulfate was removed from enzyme suspensions by centrifugation. Prostaglandin $E_{2}$ and porcine insulin were from Serva AG, Heidelberg. Highly purified human serum albumin was from Behring Werke, Marburg. Epinephrine and isoproterenol were purchased from Merck AG, Darmstadt, and Roth AG, Karlsruhe, respectively. Clonidine was a gift of Boehringer Ingelheim.

Statistics. Statistical analysis was by the Wilcoxon test for paired observations.

\section{Results}

Effects of pertussis toxin and of adenosine deaminase on basal and isoproterenol-activated cAMP accumulation and lipolysis. The time course of cAMP accumulation during exposure of human adipocytes to hormonal activators of lipolysis is less well defined than for rat adipocytes. Therefore, experiments were done in which CAMP and glycerol release were measured concomitantly at different time intervals (Fig. 1). Basal levels of cAMP averaged $20 \mathrm{pmol} / 10^{6}$ cells in this experiment. Removal of endogenous adenosine resulted in approximately a threefold increase in basal cAMP levels (Fig. $1 A$ ), which was associated with a corresponding activation of glycerol release averaging $200 \%$ above basal levels (Fig. $1 C$ ). The time course of cAMP accumulation in cells exposed to isoproterenol ( $1 \mu \mathrm{mol} / \mathrm{liter})$ showed a rapid increase to maximum levels that remained at the same increased level for $60 \mathrm{~min}$ of incubation under all conditions employed. cAMP levels rose to more than 1,000 $\mathrm{pmol} / 10^{6}$ cells in the presence of isoproterenol, while the rate of glycerol release seen under these conditions exceeded that induced by adenosine deaminase by only $25 \%$. When isoproterenol and adenosine deaminase were added together, cAMP levels were further increased (from $\sim 1,000 \mathrm{pmol} / 10^{6}$ cells to $\sim 5,000 \mathrm{pmol} / 10^{6}$ cells). However, no further increase in glycerol release was observed under these conditions.

Pretreatment of fat cells with pertussis toxin also resulted in an increase in cAMP levels which, though moderate in comparison to isoproterenol, exceeded that seen in the presence of adenosine deaminase by a factor of 2-3 (Fig. $2 \mathrm{~B}$; Table I). In the presence of isoproterenol cAMP levels rose to $10,000 \mathrm{pmol} /$ $10^{6}$ cells after pretreatment of fat cells with pertussis toxin. Adenosine deaminase had no effect on cAMP levels under these latter conditions, irrespective of whether it was added alone or in combination with isoproterenol (Fig. $2 \mathrm{~B}$ ).

After pretreatment with pertussis toxin, basal rates of glycerol release were comparable with those seen in the presence of isoproterenol in controls (Fig. $2 \mathrm{D}$ ). Neither adenosine deaminase nor isoproterenol had any further stimulatory effect. The observations that both addition of adenosine deaminase and pretreatment of human adipocytes with pertussis toxin induced considerable (adenosine deaminase) or even maximal (pertussis toxin) activation of glycerol release, whereas cAMP levels were 

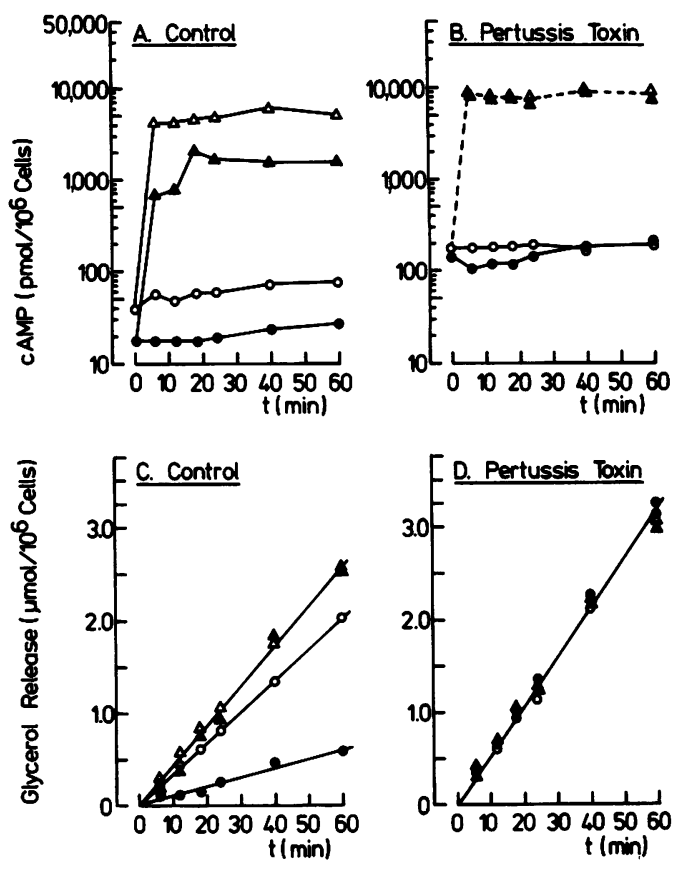

Figure 1. Effects of adenosine deaminase and of pertussis toxin on cAMP levels and on glycerol release. Fat cells were isolated from adipose tissue of one subject. The cell suspension was divided into two sets which were preincubated for $180 \mathrm{~min}$ in the presence or absence of pertussis toxin $(5 \mu \mathrm{g} / \mathrm{ml})$ as described in Methods. After washing, the cell concentrations were adjusted to $10^{5} \mathrm{cells} / \mathrm{ml}$, and both suspensions were divided into aliquots $(6 \mathrm{ml})$ containing no additions $(\bullet)$, adenosine deaminase $(1.6 \mu \mathrm{g} / \mathrm{ml} ; 0)$, or isoproterenol ( $1 \mu \mathrm{mol} / \mathrm{liter})$ either alone $(\boldsymbol{\Delta})$ or in combination with adenosine deaminase $(\Delta)$. Adenosine deaminase was added $15 \mathrm{~min}$ before the start of the time-course experiment, and the glycerol accumulating during this interval was subtracted from subsequent determinations. Isoproterenol was added at the start of the experiment. At the times indicated aliquots of 0.05 $\mathrm{ml}$ were withdrawn for assay of cAMP and glycerol, respectively. This representative experiment was repeated five times.

only modestly increased, were confirmed in eight separate experiments (Table I, Fig. 2).

Fig. 2 shows dose-response curves for isoproterenol in nontreated and pertussis toxin-treated adipocytes. Basal lipolytic rates were relatively high in these experiments, averaging $1.5 \mu \mathrm{mol} /$ $10^{6}$ cells per $180 \mathrm{~min}$. It has been common, however, to find higher nonstimulated glycerol release in obese compared to lean subjects, whereas maximal rates of lipolysis are similar in lean and obese subjects (18). In the absence of adenosine deaminase, the $\beta$-adrenergic amine caused a concentration-dependent increase in lipolysis. Maximal activation occurred at $1 \mu \mathrm{mol} /$ liter and averaged $200 \%$ above basal levels. Removal of endogenous adenosine and pretreatment of fat cells with pertussis toxin increased basal lipolytic rates without substantially altering the maximal rates achieved in the presence of isoproterenol. Therefore, addition of isoproterenol caused either a small (adenosine deaminase) or only a marginal (pertussis toxin) additional increase of lipolysis under these conditions.

Influence of pertussis toxin and of adenosine deaminase on the effects of antilipolytic agents. Fig. 3 shows the effect of various antilipolytic agents in nontreated cells and in adipocytes pretreated with pertussis toxin. Adenosine deaminase $(1.6 \mu \mathrm{g} / \mathrm{ml})$ was present throughout these experiments. In contrast to con-

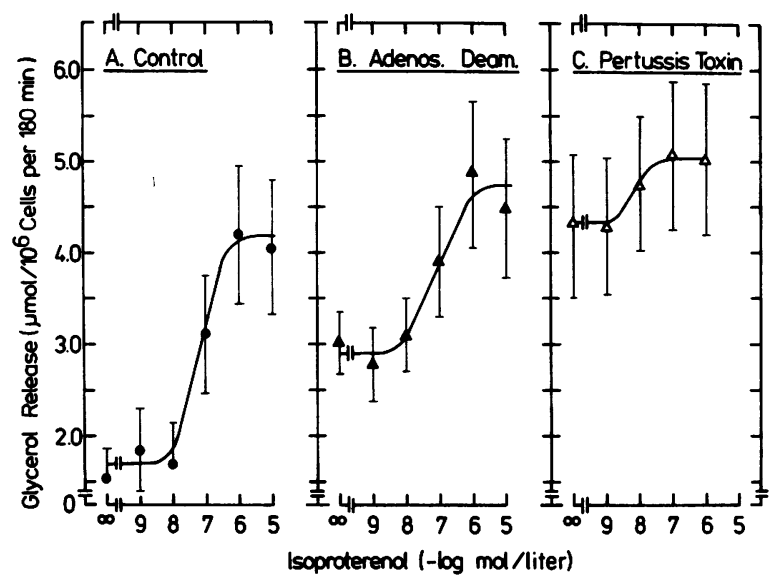

Figure 2. Influence of adenosine deaminase and of pertussis toxin treatment on the lipolytic action of isoproterenol. Fat cells were preincubated for $180 \mathrm{~min}$ in the absence and presence of $5 \mu \mathrm{g} / \mathrm{ml}$ pertussis toxin. After washing, cell densities were adjusted to 5,000-20,000 cells $/ \mathrm{ml}$, and fat cells were incubated with increasing concentrations of isoproterenol either alone $(A)$ or in combination with adenosine deaminase ( $B$ and $C$ ) in a total volume of $0.05 \mathrm{ml}$ for another $180 \mathrm{~min}$. When present, adenosine deaminase $(1.6 \mu \mathrm{g} / \mathrm{ml})$ and isoproterenol were added at the start of the final incubations. Values are means \pm standard error of four $(A)$ to five paired experiments ( $B$ and $C)$. For other details see Methods. Abbreviation: Adenos. Deam., adenosine deaminase.

trols, the antilipolytic effects of those agents known to affect lipolysis via inhibition of adenylate cyclase $\left(\mathrm{N}^{6}\right.$-phenylisopropyladenosine, prostaglandin $\mathrm{E}_{2}$, clonidine) were abolished in fat cells pretreated with pertussis toxin.

Among the agents tested, only insulin was capable of inhibiting lipolysis in toxin-treated cells. The antilipolytic action of insulin was completely unaffected with respect to effective concentration range and degree of inhibition. Time course of glycerol release and concomitant determinations of cAMP levels in the presence and absence of insulin and prostaglandin $E_{2}$, respectively, are shown in Fig. 4. In this experiment the medium contained $1.6 \mu \mathrm{g} / \mathrm{ml}$ of adenosine deaminase throughout. In control cells cAMP levels (in the presence of adenosine deaminase) ranged from 55 to $65 \mathrm{pmol} / 10^{6}$ cells and glycerol release averaged

Table I. cAMP Levels in Nontreated and Pertussis Toxin-pretreated Human Adipocytes

\begin{tabular}{lll}
\hline & \multicolumn{2}{l}{ cAMP levels } \\
\cline { 2 - 3 } Additions & Control ${ }^{*}$ & Pertussis toxin \\
\hline & $p m o l / 10^{6} \mathrm{cells}$ & $\mathrm{pmol} / 10^{6} \mathrm{cells}$ \\
$-\quad 27 \pm 5$ & $160 \pm 20 \S$ \\
$\begin{array}{l}\text { Adenosine deaminase } \\
(1.6 \mu \mathrm{g} / \mathrm{ml})\end{array}$ & $70 \pm 15 \ddagger$ & $180 \pm 25 \S$ \\
\hline
\end{tabular}

* Values are means $\pm \mathrm{SE}$ of eight separate experiments carried out with fat cells from different subjects. cAMP levels were determined at either 10 or 12 min of incubation. For experimental details, see Methods and legend to Fig. 2.

¥ Significantly higher than basal levels $(P \leqq 0.05)$.

$\S$ Significantly higher than controls $(P \leqq 0.05)$. 

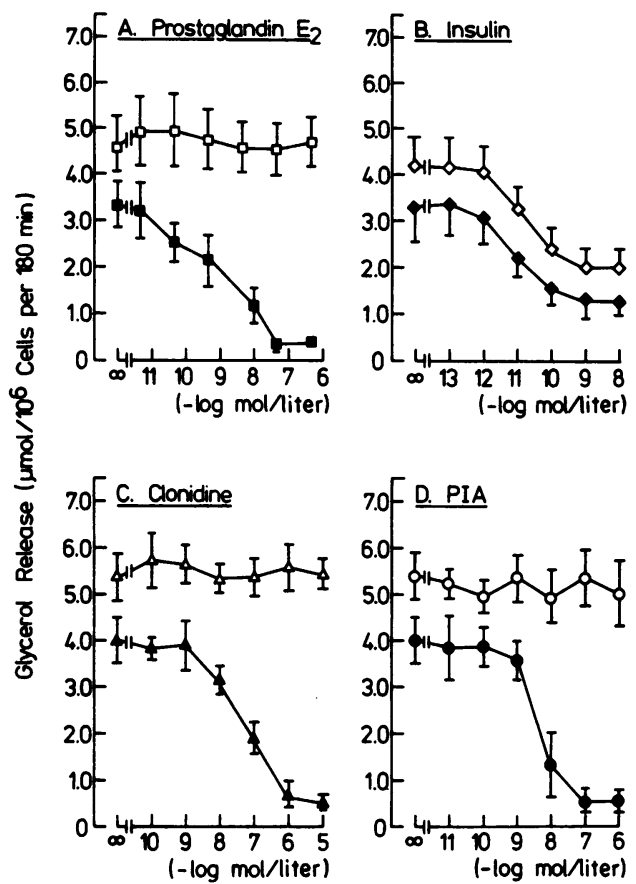

Figure 3. Effects of pertussis toxin on the antilipolytic action of prostaglandin $\mathrm{E}_{2}$, insulin, clonidine, and $\mathrm{N}^{6}$-phenylisopropyladenosine. Untreated and pertussis toxin-treated fat cells were incubated with increasing concentrations of various antilipolytic agents for $180 \mathrm{~min}$ at $37^{\circ} \mathrm{C}$. Antilipolytic agents were added at the start of the incubations. The medium contained $1.6 \mu \mathrm{g} / \mathrm{ml}$ of adenosine deaminase. Values are means \pm standard error of four $(C$ and $D)$ to six $(A$ and $B)$ paired experiments carried out in duplicate with fat cells from different subjects. For further details see Methods. Open symbols refer to pertussis toxin-treated cells; closed symbols show the respective controls. Abbreviation: PIA, $\mathrm{N}^{6}$-phenylisopropyladenosine.

$1.6 \mu \mathrm{mol} / 10^{6}$ cells per $60 \mathrm{~min}$. Prostaglandin $\mathrm{E}_{2}(50 \mathrm{nmol} / \mathrm{liter})$ depressed cAMP levels to $30 \mu \mathrm{mol} / 10^{6}$ cells. Concomitantly, glycerol release was decreased to $0.4 \mu \mathrm{mol} / 10^{6}$ cells per $60 \mathrm{~min}$. Insulin reduced the rate of glycerol release from $1.6 \mu \mathrm{mol} / 10^{6}$ cells per $60 \mathrm{~min}$ to $\sim 1.0 \mu \mathrm{mol} / 10^{6}$ cells per $60 \mathrm{~min}$. In contrast to prostaglandin $E_{2}$, insulin had no measurable effect on cAMP levels under the conditions employed, indicating that in human
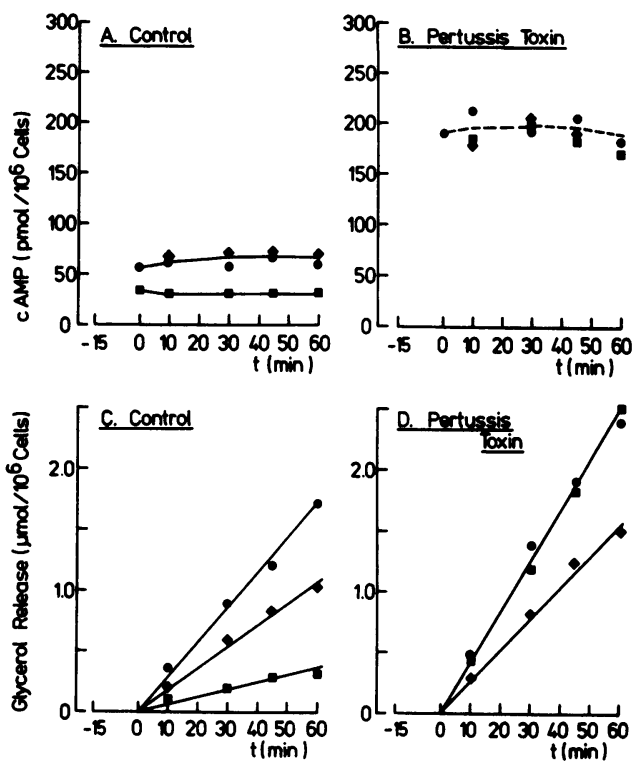

Figure 4. Effects of insulin and of prostaglandin $E_{2}$ on cAMP accumulation and glycerol release in nontreated and pertussis toxin-treated adipocytes. Experimental conditions were similar to those described for Fig. 1 except that not only adenosine deaminase $(1.6 \mu \mathrm{g} / \mathrm{ml})$ but also hormones were added $15 \mathrm{~min}$ before the start of the experiment. Glycerol accumulating between $-15 \mathrm{~min}$ and $0 \mathrm{~min}$ was subtracted from subsequent determinations. This representative experiment was repeated six times (Table II). For further details see legend to Fig. 1 and Methods. Symbols: •, control; •, insulin (10 nmol/liter); $₫$, prostaglandin $\mathrm{E}_{2}(50 \mathrm{nmol} /$ liter $)$.

fat cells insulin can exert antilipolytic effects although cAMP levels remain unchanged.

In cells treated with pertussis toxin, glycerol release averaged $2.5 \mu \mathrm{mol} / 10^{6}$ cells per $60 \mathrm{~min}$. The inhibitory action of prostaglandin $\mathrm{E}_{2}$ was completely abolished, consistent with the data shown in Fig. 4, whereas the antilipolytic effect of insulin was preserved in toxin-treated cells. Not only insulin but also prostaglandin $\mathrm{E}_{2}$ failed to decrease cAMP after the cells had been treated with pertussis toxin.

The lack of effect of insulin on cAMP levels was confirmed in six separate experiments carried out with different cell prep-

Table II. Effects of Insulin and Prostaglandin $E_{2}$ on cAMP Accumulation and Lipolysis in Nontreated and Pertussis Toxin-treated Human Adipocytes

\begin{tabular}{|c|c|c|c|c|c|c|}
\hline \multirow[b]{3}{*}{ Additions } & \multicolumn{3}{|l|}{ Control* } & \multicolumn{3}{|l|}{ Pertussis toxin } \\
\hline & \multicolumn{2}{|l|}{ cAMP } & \multirow[b]{2}{*}{ Glycerol release } & \multicolumn{2}{|l|}{ cAMP } & \multirow[b]{2}{*}{ Glycerol release } \\
\hline & at $12 \mathrm{~min}$ & at $24 \mathrm{~min}$ & & at $12 \mathrm{~min}$ & at $24 \mathrm{~min}$ & \\
\hline & pmol/ $/ 10^{6}$ cells & pmol/10 $10^{6}$ cells & $\mu \mathrm{mol} / 10^{6}$ cells per $60 \mathrm{~min}$ & pmol/10 cells & pmol/10 cells & 4mol $/ 10^{6}$ cells per $60 \mathrm{~min}$ \\
\hline- & $65 \pm 15$ & $72 \pm 20$ & $1.8 \pm 0.1$ & $200 \pm 30$ & $220 \pm 40$ & $2.8 \pm 0.3$ \\
\hline $\begin{array}{r}\text { Prostaglandin } E_{2} \\
(50 \mathrm{nmol} / \mathrm{liter})\end{array}$ & $35 \pm 10 \ddagger$ & $40 \pm 10 \ddagger$ & $0.3 \pm 0.05 \ddagger$ & $193 \pm 30$ & $200 \pm 40$ & $2.9 \pm 0.2$ \\
\hline Insulin & & & & & & \\
\hline (10 nmol/liter) & $73 \pm 15$ & $80 \pm 15$ & $1.1 \pm 0.1 \ddagger$ & $210 \pm 30$ & $215 \pm 30$ & $1.8 \pm 0.1 \ddagger$ \\
\hline
\end{tabular}

\footnotetext{
* Values are means \pm standard error of six paired experiments carried out in duplicate with fat cells of different subjects. The medium contained $1.6 \mu \mathrm{g} / \mathrm{ml}$ of adenosine deaminase under both conditions. For experimental details, see Methods and legend to Fig. 2 . $¥$ Significantly lower than control values $(P=0.05)$.
} 
arations (Table II). For comparison, the effects of prostaglandin $E_{2}$, which is known to act via inhibition of adenylate cyclase, were tested simultaneously. Prostaglandin $\mathrm{E}_{2}$ consistently reduced cAMP levels by $\sim 50 \%$ whereas insulin failed to induce a detectable inhibition of cAMP levels under the conditions employed. The effects of insulin on cAMP accumulation are complex and have frequently been shown to depend on the insulin concentration used (1). Therefore, additional time-course studies $(n=3)$ were carried out using four different insulin concentrations ranging from $10 \mathrm{pmol} /$ liter to $10 \mathrm{nmol} /$ liter. However, even under these conditions no decrease of cAMP levels could be detected (not shown). In order to exclude the possibility that insulin only transiently decreased cAMP levels, three other experiments were carried out in which cAMP levels were determined at 1, 5, and $10 \mathrm{~min}$ after the addition of the hormone (10 nmol/liter). However, no short-term change in cAMP concentrations could be detected.

\section{Discussion}

Effects of pertussis toxin and of adenosine deaminase on basal and isoproterenol-activated rates of cAMP accumulation and glycerol release. Fat cells produce and extrude inhibitory regulators such as adenosine or prostaglandins of the E type (1-8). As reported previously and shown in Fig. 1 and 2, even extremely dilute suspensions of human adipocytes produce adenosine in amounts sufficient to depress glycerol release substantially (19). In the present studies, both removal of endogenous adenosine and treatment of adipocytes with pertussis toxin resulted in an increase of cAMP. Lipolysis was considerably activated when cAMP levels were increased two- to threefold (adenosine deaminase) and proceeded at maximal rates after treatment with pertussis toxin which was associated with about a five- to sevenfold increase in cAMP levels. These results are consistent with the widely held belief that only a small increase in total cyclic AMP is necessary to stimulate lipolysis fully. The fact that pretreatment of fat cells with pertussis toxin resulted in higher cAMP levels than removal of endogenous adenosine could suggest either that some tightly-bound adenosine is not accessible to adenosine deaminase or that adenosine is not the only inhibitor produced during incubations in vitro. Support for the latter possibility comes from studies of Chang et al. (8), who showed that human adipocytes also produce prostaglandins of the $E$ and $F$ types. Similar explanations may apply to the observation that cAMP levels elevated by isoproterenol (in the presence of adenosine deaminase) were further increased by pertussis toxin treatment. The latter effect of pertussis toxin can also be explained by assuming that binding of isoproterenol to its receptor causes not only activation of CAMP formation via the stimulatory nucleotide binding-protein of adenylate cyclase $\left(N_{\mathrm{s}}\right)$, but also simultaneous inhibition via the inhibitory coupling protein $\left(N_{\mathrm{i}}\right)$, as proposed by Murayama and Ui (20) for rat adipocytes.

Reversal by pertussis toxin of the inhibitory effects of $N^{6}$. phenylisopropyladenosine, prostaglandin $E_{2}$, and clonidine. As in the rat fat cell, pretreatment of human adipocytes with pertussis toxin abolished the antilipolytic effects of $\mathrm{N}^{6}$-phenylisopropyladenosine and prostaglandin $\mathrm{E}_{2}(10,11,13)$. Concomitantly the decrease of cAMP levels produced by both agents was reversed. Rat adipocytes contain no functional $\alpha_{2}$-receptors. In human fat cells the $\alpha_{2}$-adrenergic effects of epinephrine (not shown) and of clonidine were also blocked (Fig. 3). Pertussis toxin catalyzes the ADP ribosylation in various cell types including fat cells of a $41,000-\mathrm{mol}$ wt protein that is apparently a subunit of $N_{\mathrm{i}}$, the inhibitory guanine nucleotide binding-protein of adenylate cyclase (for review see References 21 and 22). The covalent modification inhibits the functional ability of inhibitory receptors to depress cAMP formation (21-23). cAMP levels were increased in adipocytes pretreated with pertussis toxin and reversal of the antilipolytic effect of prostaglandin $E_{2}$ was associated with a corresponding increase of CAMP, suggesting that adenylate cyclase is in fact involved. However, several effects of pertussis toxin have been described which are independent of cyclic nucleotide changes $(21,22,24)$. In addition, the concentration of pertussis toxin used in this study was more than 10-fold higher than that used by others with rat adipocytes (13). Therefore, we cannot exclude the possibility that mechanisms other than modification of adenylate cyclase are also important.

The role of adenosine and of E-type prostaglandins as physiologic regulators of adipose tissue is unknown at present. However, there is mounting evidence from in vitro experiments suggesting that local regulators are important in long-term regulation of lipolysis of different species including humans (1-3, 25-29). Previous studies with adipocytes of starved subjects led us to conclude that the increase in basal lipolytic rate seen in starvation is mainly due to relief of endogenous inhibition (19). The results of the present studies are consistent with this view. They demonstrate that relief of endogenous inhibitory influences results in almost maximal stimulation of glycerol release, suggesting that the primary functional state which is attained in the absence of any regulators is characterized by high rates of glycerol release. Therefore, a certain degree of inhibition appears to be necessary for fat cell lipolysis to be susceptible to activation.

Effects of insulin. In contrast to all other inhibitors tested, the antilipolytic action of insulin was preserved after pretreatment of adipocytes with pertussis toxin. In addition, although the antilipolytic effect was clearly manifested, the peptide hormone had no inhibitory effects on cAMP accumulation regardless of whether the cells had or had not been treated with pertussis toxin.

The $\beta$-oligomer of pertussis toxin has been shown to have insulinlike effects on glucose oxidation in rat adipocytes (24). The observations of the present studies, however, are almost certainly not related to this subunit, which mediates binding of the holotoxin to the cell surface, because basal glycerol release should have been decreased rather than increased if the $\beta$-oligomer, in addition to its effects on glucose oxidation also had insulinlike antilipolytic effects.

The antilipolytic effect of insulin has often been correlated with a decrease in cAMP concentrations in adipose tissue, and some investigators have proposed that this decrease in cAMP level fully explains the antilipolytic action of this hormone in fat cells of different species including human adipocytes (3033; for review see Reference 34).

The cAMP response of adipocytes to lipolytic agents often does not reach a steady state, but shows a peak followed by a decline $(1,35)$. The sharpness of the peak has been found to be very variable $(1,35)$. A possible explanation for this variability comes from studies of Engfeldt et al. (35), who showed that phosphodiesterase activity is reduced by collagenase digestion of human adipose tissue. In the present studies, cAMP accumulation in cells exposed to isoproterenol showed a rapid increase to maximum level that remained at the same increased level for $60 \mathrm{~min}$. Similar time courses in cAMP response were 
reported from hamster adipocytes (36). Insulin is known to activate a low- $K_{\mathrm{m}}$ phosphodiesterase (1). In view of the findings of Engfeldt et al. (35), we cannot exclude the possibility that phosphodiesterase activity was sufficiently reduced to preclude any insulin-induced activation of phosphodiesterase. In addition, in cultured 3T3- $\mathrm{L} 1$ adipocytes insulin activation of phosphodiesterase is prevented by pertussis toxin treatment (37). If applicable to human adipocytes, these latter findings would explain why cAMP levels were not changed by insulin after treatment with pertussis toxin. In addition, the effects of insulin were assessed only with glucose in the medium. Hence, we do not know whether changes of cAMP would have occurred in the absence of glucose. We, therefore, do not suggest that insulin has not effects on cAMP levels at all. However, our observations demonstrate that changes in cAMP levels cannot offer a satisfactory explanation for the mechanisms of the antilipolytic action of insulin under all conditions. This conclusion is consistent with recent reports in which rat adipocytes were employed that had been made permeable by digitonin, or pharmacologic manipulations to bypass endogenous CAMP production and utilization $(38-40)$. These latter studies consistently showed that the antilipolytic effect of insulin does not require adenylate cyclase or phosphodiesterase action (38-40).

In conclusion, the results show that the antilipolytic effect of insulin is not necessarily related to measurable decreases of cAMP. Additional evidence that the mechanisms underlying the antilipolytic action of insulin is different from the mechanisms of other antilipolytic compounds comes from the observation that pertussis toxin blocks the inhibitory action of prostaglandin $E_{2}, N^{6}$-phenylisopropyladenosine, and clonidine without affecting the antilipolytic action of insulin. The peptide hormone is the only antilipolytic regulator shown to be physiologically important in vivo. In vitro, lipolysis is severely restrained by endogenous inhibitors, of which adenosine is probably the most important. Unrestrained lipolysis proceeds at almost maximal rates, suggesting that a certain degree of inhibition might be necessary for fat cell lipolysis to be susceptible to stimulation. Further information about the concentrations of adenosine and prostaglandins within adipose tissue in vitro and in vivo, therefore, would be of great value in gaining more detailed insights into the mechanisms that adjust lipid mobilization to the actual demands of the organism.

\section{Acknowledgments}

The authors are grateful to Miss E. Messmer and Miss U. Biehl for skillful technical assistance and are indebted to Mrs. C. Brown for careful preparation of the manuscript. We wish to thank Dr. P. D. Wood, Stanford University, Stanford, California, for proofreading the manuscript.

This work was supported by grants of the Deutsche Forschungsgemeinschaft, Bonn-Bad Godesberg; the Thyssen-Stiftung, Cologne; and the Bundesministerium für Forschung und Technologie, Bonn, Federal Republic of Germany.

\section{References}

1. Hales, C. N., J. P. Lucio, and K. Siddle. 1978. Hormonal control of adipose-tissue lipolysis. Biochem. Soc. Symp. 43:97-135.

2. Kather, H. 1981. Hormonal regulation of adipose tissue lipolysis in man: Implications for the pathogenesis of obesity. Triangle. 20:131143.

3. Fain, J. N., and C. C. Malbon. 1979. Regulation of adenylate cyclase by adenosine. Mol. Cell. Biochem. 25:143-169.
4. Schwabe, U., P. S. Schöndörfer, and R. Ebert. 1974. Facilitation by adenosine of the action of insulin on the accumulation of adenosine $3^{\prime}: 5^{\prime}$ monophosphate, lipolysis and glucose oxidation in isolated fat cells. Eur. J. Biochem. 46:537-545.

5. Ohisalo, J. J. 1981. Effects of adenosine on lipolysis in human subcutaneous fat cells. J. Clin. Endocrinol. Metab. 52:359-363.

6. Kather, H., and B. Simon. 1979. Biphasic effects of prostaglandin $\mathrm{E}_{2}$ on human fat cell adenylate cyclase. J. Clin. Invest. 64:609-612.

7. Kather, H., and B. Simon. 1981. Adrenoceptor of the alpha ${ }_{2-}$ subtype mediating inhibition of the human fat cell adenylate cyclase. Eur. J. Clin. Invest. 11:111-114.

8. Chang, J., G. P. Lewis, and P. J. Piper. 1977. Inhibition by glucocorticoids of prostaglandin release from adipose tissue in vitro. $\mathrm{Br}$. J. Pharmacol. 59:425-432.

9. Yajima, M., K. Hosoda, Y. Kanbayashi, T. Nakamura, J. Takahashi, and M. Ui. 1978. Biological properties of islet-activating protein (IAP) purified from the culture medium of Bordetella pertussis. J. Biochem. (Tokyo). 83:305-312.

10. Kather, H., K. Aktories, G. Schultz, and K. H. Jakobs. 1983. Islet-activating protein discriminates the antilipolytic mechanism of insulin from that of other antilipolytic compounds. FEBS (Fed. Eur. Biochem. Soc.) Lett. 161:149-152.

11. Moreno, F. J., I. Mills, J. A. Gárcia-Sáinz, and J. N. Fain. 1983. Effects of pertussis toxin treatment on the metabolism of rat adipocytes. J. Biol. Chem. 258:10938-10943.

12. Gárcia-Sáinz, J. A. 1981. Decreased sensitivity to alpha 2 -adrenergic amines, adenosine and prostaglandins in white fat cells from hamsters treated with pertussis vaccine. FEBS (Fed. Eur. Biochem. Soc.) Lett. 126:306-308.

13. Olansky, L., G. A. Myers, S. L. Pohl, and E. L. Hewlett. 1983. Promotion of lipolysis in rat adipocytes by pertussis toxin: reversal of endogenous inhibition. Proc. Natl. Acad. Sci. USA. 80:6547-6551.

14. Rodbell, M. 1964. Metabolism of isolated fat cells. J. Biol. Chem. 239:375-384.

15. Cowell, J. L., Y. Sato, H. Sato, B. An der Lan, and C. Manclark. 1982. Separation, purification and properties of the filamentous hemagglutinin and the leukocytosis promoting factor-hemagglutinin from Bordetella pertussis. Semin. Infect. Dis. 4:371-379.

16. Kather, H., F. Schröder, and B. Simon. 1982. Microdetermination of glycerol using bacterial NADH-linked luciferase. Clin. Chim. Acta. 120:295-300.

17. Kather, H., and E. Wieland. 1984. Glycerol. Luminometric method. In Methods of Enzymatic Analysis. Vol. VI. H. U. Bergmeyer, editor. Verlag Chemie Weinheim, Federal Republic of Germany. 510518.

18. Arner, P., J. Bolinder, P. Engfeldt, J. Hellmér, and J. Östman. 1984. Influence of obesity on the antilipolytic effect of insulin in isolated human fat cells obtained before and after glucose ingestion. J. Clin. Invest. 73:673-680.

19. Kather, H., E. Wieland, B. Fischer, A. Wirth, and G. Schlierf. 1985. Adrenergic regulation of lipolysis in adipocytes of obese subjects during caloric restriction. Reversal of catecholamine-action caused by relief of endogenous inhibition. Eur. J. Clin. Invest. 15:30-37.

20. Murayama, T., and M. Ui. 1983. Loss of the inhibitory function of the guanine nucleotide regulatory component of adenylate cyclase due to its ADP-ribosylation by islet-activating protein, pertussis toxin, in adipocyte membranes. J. Biol. Chem. 258:3319-3326.

21. Hewlett, E. L., M. J. Cronin, J. Moss, H. Anderson, G. A. Myers, and R. D. Pearson. 1984. Pertussis toxin: lessons from biological and biochemical effects in different cells. Adv. Cyclic Nucleotide Res. 17: 173-182.

22. Ui, M., T. Katada, T. Murayama, H. Kurose, M. Yajima, M. Tamura, T. Nakamura, and K. Nogimori. 1984. Islet-activating protein: a specific uncoupler of receptor-mediated inhibition of adenylate-cyclase. Adv. Cyclic Nucleotide Res. 17:145-151.

23. Hildebrandt, J. P., R. D. Sekura, J. Codina, R. Jyengar, C. R. Manclark, and L. Birnbaumer. 1983. Stimulation and inhibition of ad- 
enylate cyclase mediated by distinct regulatory proteins. Nature (Lond.). 302:706-709.

24. Tamura, M., K. Nogimori, M. Yajima, K. Ase, and M. Ui. 1983. A role of the $\beta$-oligomer moiety of islet-activating protein, pertussis toxin, in development of the biological effects on intact cells. J. Biol. Chem. 258:6756-6761.

25. Hoffman, B. B., H. Chang, Z. Farahbakhsh, and G. Reaven. 1984. Inhibition of lipolysis by adenosine is potentiated with age. J. Clin. Invest. 74:1750-1755.

26. Vernon, R. G., E. Finley, and E. Taylor. 1983. Adenosine and the control of lipolysis in rat adipocytes during pregnancy and lactation. Biochem. J. 216:121-128.

27. Ohisalo, J. J., and J. E. Stouffer. 1979. Adenosine, thyroid status and regulation of lipolysis. Biochem. J. 178:249-251.

28. Saggerson, D. E. 1980. Increased antilipolytic effects of the adenosine "R-site" agonist $\mathrm{N}^{6}$-(phenylisopropyl)adenosine in adipocytes from adrenalectomized rats. FEBS (Fed. Eur. Biochem. Soc.) Lett. 115:127128.

29. Rosenquist, U., and S. Efendić. 1971. Stimulatory effect in vitro of prostaglandin $E_{1}$ on noradrenaline-induced lipolysis in subcutaneous adipose tissue from hypothyroid subjects. Acta Med. Scand. 190:341345.

30. Wong, E. H.-A., and E. G. Loten. 1981. The antilipolytic action of insulin on adrenocorticotrophin-stimulated rat adipocytes. The roles of adenosine $3^{\prime}: 5^{\prime}$ monophosphate and the protein kinase dependent on adenosine 3':5' monophosphate. Eur. J. Biochem. 115:17-22.

31. Zapf, J., M. Waldvogel, and E. R. Froesch. 1981. Is increased basal lipolysis in adipose tissue of fasted-refed rats related to cyclic AMPdependent mechanisms? Eur. J. Biochem. 119:453-459.

32. Arner, P. 1976. Relationship between intracellular cyclic AMP and lipolysis in human adipose tissue. Acta Med. Scand. 200:179-186.

33. Burns, T. W., B. E. Terry, P. E. Langley, and G. A. Robison. 1979. Insulin inhibition of lipolysis of human adipocytes. The role of cyclic adenosine monophosphate. Diabetes. 28:957-961.

34. Denton, R. M., R. H. Brownsey, and G. J. Belsham. 1981. A partial view on the mechanism of insulin action. Diabetologia. 21:347362.

35. Engfeldt, P., P. Arner, and J. Östman. 1980. Influence of adipocyte isolation by collagenase on phosphodiesterase activity and lipolysis in man. J. Lipid Res. 21:443-448.

36. Schimmel, R. J. 1984. Stimulation of cAMP accumulation and lipolysis in hamster adipocytes with forskolin. Am. J. Physiol. 246:C63C68.

37. Elks, M. L., P. A. Watkins, V. C. Manganiello, J. Moss, E. Hewlett, and $M$. Vaughan. 1983. Selective regulation by pertussis toxin of insulininduced activation of particulate cAMP phosphodiesterase activity in 3T3-L1 adipocytes. Biochem. Biophys. Res. Commun. 116:593-598.

38. Mooney, R. A., R. D. Ebersohl, and J. M. McDonald. 1984. Insulin-mediated antilipolysis in permeabilized rat adipocytes. J. Biol. Chem. 259:7701-7704.

39. Shechter, Y. 1984. Differential effects of two phosphodiesterase inhibitors on fat cell metabolism. Endocrinology. 115:1787-1791.

40. Gabbay, R. A., and H. A. Lardy. 1985. The antilipolytic effect of insulin does not require adenylate cyclase or phosphodiesterase action. FEBS (Fed. Eur. Biochem. Soc.) Lett. 179:7-11. 